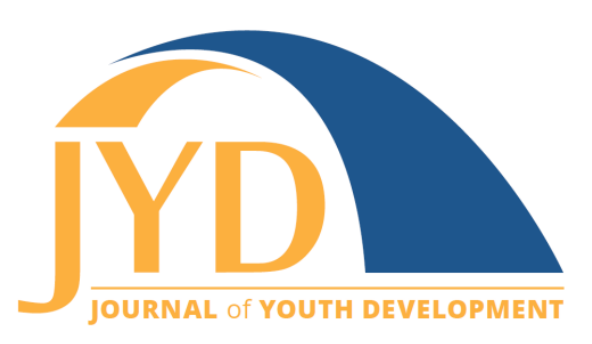

http://jyd.pitt.edu/ | Vol. 15 Issue 2 DOI 10.5195/jyd.2020.962 | ISSN 2325-4017 (online)

\title{
Positive Youth Development Through Leisure: Confronting the COVID-19 Pandemic
}

\author{
Andrea Vest Ettekal \\ Recreation, Park, and Tourism Sciences, Texas A\&M University \\ andrea.ettekal@tamu.edu
}

Jennifer P. Agans

Recreation, Park, and Tourism Management, The Pennsylvania State University

jxa912@psu.edu

\begin{abstract}
The COVID-19 pandemic has caused significant disruption in the lives of millions of people, including children and adolescents. Youth out-of-school time (OST) programs are essential ecological assets and their disruption during the pandemic may have a major impact on youth developmental pathways. Youth programs are one of the primary ways to promote positive youth development (PYD) and, in turn, develop healthy and thriving young adults who contribute positively to society. The pandemic raises the question of how to sustain developmentally oriented forms of youth leisure in times of crisis and, especially, how to support youth with few resources. Although there is considerable scientific evidence regarding the promotion of PYD through OST programs (e.g., sport, clubs, youth groups), public health initiatives to control the pandemic also curtail the delivery of such programs. Nevertheless, research on youth programs can be applied to help support PYD during the pandemic. In this commentary, we review key elements contributing to the effectiveness of youth development programs and provide ideas for how to sustain, adapt, and create these elements and bring them into unstructured leisure settings in the face of the pandemic. In doing so, we highlight particular challenges to implementation, surmise who may be most at risk, and present potential opportunities afforded by the unique situation. Throughout, we highlight innovative examples of adaptation exhibited in affected communities. We conclude with a call to action for researchers and practitioners to unite efforts to support PYD through leisure even in the face of crisis.
\end{abstract}

Key words: pandemic, leisure, out-of-school time, positive youth development, "Big Three" features

The COVID-19 pandemic has caused significant disruption in the lives of millions of people around the world, including children and adolescents. Whether affected by the pandemic

(c) EY $\mathrm{EY}$ New articles in this journal are licensed under a Creative Commons Attribution 4.0 License. This journal is published by the University Library System, University of Pittsburgh and is cosponsored by the University of Pittsburgh Press. The Journal of Youth Development is the official peer-reviewed publication of the National Association of Extension 4-H Youth Development Professionals and the National AfterSchool Association. 
directly through infection of self or immediate family members, or indirectly through the many policies and regulations implemented to slow the spread of the virus, the pandemic is certain to have an immediate and long-lasting impact on youth. Many youth are attending school virtually and are navigating school-home environments with myriad physical and mental distractions. The pandemic renders a paradox for youth leisure: youth leisure opportunities are restricted, such as the many out-of-school time (OST) programs that have come to an abrupt halt due to the challenges of adapting to the virtual environment; yet the restrictions that accompany the pandemic, such as shelter-in-place guidelines, may present youth with more free time than ever before. This leisure paradox begs the question of whether and how to engage youth in forms of leisure that intentionally contribute to their positive development. We contend that youth leisure can be leveraged during the pandemic to support positive youth development (PYD), but also acknowledge the many barriers to leisure for youth and families. In this commentary, we draw from youth development theory, research, and practice to provide ideas about sustaining, adapting, or creating developmentally oriented leisure opportunities for youth during the pandemic. Although we focus this commentary on OST in the United States, we recognize that innovative examples of leisure adaptation during the pandemic are taking place around the globe. We conclude with a call to action for researchers and practitioners to unite in support of youth in the face of this international catastrophe.

\section{The Meaning of Leisure During the Pandemic}

Youth leisure and OST are common terms in the youth development field but are used somewhat differently in developmental and recreation sciences. In recreation science, leisure is a phenomenon that provides opportunities for meaning and self-actualization and is defined as specific activities, settings, or (free) time (e.g., social or sport activities), or specific cognitions, emotions, or experiences (e.g., flow), that provide such opportunities (Walker et al., 2019). Developmental science defines leisure as what youth do during their OST hours. After sleep and school, youth experience a large amount of free time (i.e., 5.5 hours per day or about $57 \%$ of available time; U.S. Department of Labor, 2018) and what youth do during that free time impacts their development considerably (Mahoney et al., 2009). An important distinction in developmental science is that not all leisure is developmental; structured leisure (e.g., OST programs) is more effective to promote PYD than unstructured leisure (e.g., hanging out with friends) as it is linked to increased challenge, autonomy, and initiative (Larson, 2000). 
The catch during the pandemic is that all time is OST for many youth (e.g., Pittman, 2020) which muddies the meaning of OST in developmental science. Moreover, the distinction between unstructured and structured leisure is especially important in the present moment, as available leisure time increases for young people along with a simultaneous decrease in their ability to participate in structured leisure. There is a high risk of neglecting structured leisure and allowing unstructured leisure to consume youth lives during the pandemic. As such, we provide the conceptual basis for PYD through the OST lens. We then turn deliberately to what we call developmentally oriented leisure (a blend of structured and unstructured leisure) to provide a practical way to promote PYD through leisure during the pandemic.

\section{Ecological Systems Theory: Youth Development in the Context of a Pandemic}

Many researchers and practitioners utilize ecological systems theory (Bronfenbrenner \& Morris, 2006) to understand how OST matters for youth development (e.g., Ettekal \& Mahoney, 2017), recognizing that development occurs through an interrelated system of individuals and multiple, nested settings. Youth interactions with their immediate settings-including OST programs, families, and schools-represent the "engine" of the ecological system. These settings are interconnected, for example, through OST program leaders', parents', and teachers' communications with one another. Peripherally connected settings, such as parents' work, also impact youth development by shaping what occurs within and across immediate settings (this is especially true during the pandemic for youth with parents working from home). The cultural or political characteristics of society constitute the broader setting within which the system operates and, in the face of the pandemic, includes the social distancing restrictions and shelter-in-place guidelines instituted by local, state, and federal governments.

The pandemic is a unique and major historical event, which has immediate and enduring effects on the ecological systems of everyone experiencing it. During the pandemic, youth ecological systems are in turmoil, encountering changes in the routines and habits associated with daily life, interruptions in information flow and communication patterns across settings, and intense and abrupt changes in rules and regulations. PYD is supported by the integration and synergism of developmental efforts across the multiple settings which contribute to the ecological system (Lerner, Lerner, \& Benson, 2011). OST programs are critical assets to promote positive development and, as such, should be sustained, adapted, and innovated to enhance their effectiveness during the pandemic. Moreover, the principles of effective youth OST programs should be integrated with families and schools as these settings meld together during the 
pandemic. We contend that by understanding and applying what is known about PYD through OST programs, the system can be adapted to support youth.

Research on structured OST programs can be applied to help support youth even amidst the social distancing recommendations and shelter-in-place policies being implemented to slow the spread of COVID-19. Researchers, practitioners, and families can draw on what is known about the ways in which structured OST programs promote PYD (e.g., Larson et al., 2004; Lerner, Lerner, Lewin-Bizan, et al., 2011; Roth \& Brooks-Gunn, 2003) to continue to support the development of young people in this difficult time. To aid in these efforts, we review the elements contributing to the effectiveness of structured OST programs and provide ideas for how to sustain, adapt, and create these elements and bring them into unstructured leisure settings in the face of the pandemic. We embed hyperlinks throughout, leading the reader to relevant news articles or websites with resources to support youth during the pandemic.

\section{Developmentally Oriented Leisure During the Pandemic: Lessons from the}

\section{Big Three}

There are a variety of models available to help researchers and practitioners understand how to promote PYD. Here, we focus on the Big Three (Lerner, Lerner, Lewin-Bizan, et al., 2011) given its brevity relative to some other models (e.g., Search Institute's developmental assets model; Benson et al., 2011), its longer history relative to some other models (e.g., Nagaoka et al., 2015; Arnold, 2018), and its conceptual simplicity relative to some other models (e.g., science of learning and development; Cantor et al., 2019; Osher et al., 2020). Although a review of these models is not within the scope of this commentary, they are reasonable places for readers to seek out alternate approaches. As any model utilized to support youth during the pandemic will need to be adapted to align with the current pandemic conditions, we provide an example of such adaptation using the Big Three model of PYD.

The Big Three is a useful model to adapt during the pandemic because it distills the elements of structured OST programs that contribute to PYD into three features (e.g., Lerner, Lerner, Lewin-Bizan, et al., 2011): relationships with adult leaders, skill-building activities, and meaningful youth leadership. Each of these is briefly elaborated on below and expanded on in the next sections. 
First, OST programs provide opportunities for sustained relationships with a caring (nonparental) adult who is predictably available. Adult-youth relationships come in many forms (e.g., mentor, coach, leader) and can be formal or informal; the key is consistency. Disruptions in adult-youth relationships can be extremely detrimental, such that relationships terminated early or without the consent of the youth can cause more harm than good (e.g., Grossman \& Rhodes, 2002). The pandemic poses the need to be flexible and proactive in sustaining adultyouth relationships while social distancing measures are enacted. Encouraging OST staff to proactively stay connected is important-for the youth and for the future of the program. Second, OST programs provide skill-building activities that develop youth strengths. That is, activities should have an intentional focus on developing specific life skills, including a range of cognitive, behavioral, and social relational skills (e.g., intentional self-regulation, sense of agency). OST practitioners will need to be innovative in adapting or creating activities that engage youth and their families during the pandemic. The pandemic may also raise the opportunity for some youth to identify new interests and develop new skills. Third, OST programs provide youth with opportunities for leadership of valued family, school, and community activities. The key to leadership activities is that they are directly relevant and meaningful in youth lives. The pandemic presents a range of old and new leadership opportunities for youth to support families and communities affected by the pandemic (including their own families). The challenge will be deciding whether and how to sustain existing leadership initiatives and/or turn toward pandemic-specific initiatives.

\section{Special Considerations for the Big Three}

Sustaining, adapting, or creating opportunities for the Big Three will be more or less challenging for some youth. The OST agenda has often focused on addressing challenges to participation based on culture and social class (e.g., Bouffard et al., 2006; Simpkins et al., 2005; Ettekal et al., 2020). However, recalling the disrupted ecological systems described earlier, the pandemic presents a situation that transcends and potentially exacerbates these issues, creating a constellation of impacts on youth development that interrelate in important ways. We consider several elements that may cause increased challenges for some youth, such as financial resources, family configurations, and social capital. However, we recognize that these elements, although often tied to culture and social class, may have cross-cutting impacts during the pandemic. For example, youth whose parents work in hospitals will be under additional stress regardless of whether their parents are janitors or surgeons; affluent families may have access to resources outside of the home (e.g., paid services), but resources inside the home may be significantly altered (e.g., if both parents are working from home); working parents may be 
challenged to continue working (e.g., struggles to find child care in the face of daycare and school closures); non-working parents may be experiencing financial duress from not working (e.g., unemployment levels have reached record highs during the pandemic); and so on. Our point is to suggest that families are challenged by the pandemic in myriad ways, which we highlight throughout. We recognize the importance of the intersections of these challenges with pre-pandemic marginalization, while also noting how the present moment can be leveraged to support PYD for all types of youth and families.

\section{Challenges, Opportunities, and Innovations: Youth Leisure During the Pandemic}

OST programs are ecological assets to promote PYD, but there are many challenges to their implementation during the pandemic. Therefore, we focus on the elements of OST programs that are known to promote PYD. As such, we advocate for semi-structured leisure activities: activities that incorporate the Big Three features of effective OST programs, but that are modified to be delivered in newly structured or unstructured ways. Youth leisure can be developmental to the extent that it incorporates the Big Three features of effective OST programs.

\section{Caring Adult Leaders}

The first of the Big Three features is non-parental adult leaders who provide youth with support and guidance, and help youth feel connected, cared about, and valued (e.g., Lerner, Lerner, Lewin-Bizan, et al., 2011). Youth who are not involved in programs may find adult mentorship through community leaders, extended family members (e.g., grandparents), or teachers, among others (e.g., Bowers et al., 2012). Youth need relationships with adults during the pandemic, for example, to help them understand restrictions and guidelines, navigate challenges of virtual learning environments, or cope with stress induced by the pandemic. However, youth may struggle to feel emotionally connected in virtual spaces and may have limited space (mentally or physically) to discuss difficult topics in private. Moreover, ensuring youth safety in virtual spaces (e.g., monitoring of private electronic communications) can add stress for parents and caregivers. Some youth may therefore experience significant barriers to maintaining relationships with adults during the pandemic, such as disrupted contact with teachers and OST program leaders, and lack of access to technology or Internet resources (e.g., youth who live in homes with several people competing for limited resources that are now 
in high demand). Youth will need to be proactive in seeking out and maintaining relationships with adults, and adults should prioritize staying connected to youth and understanding their needs.

Virtual meetings are the "bread and butter" of the pandemic. Some youth may be averse to virtual meetings and unfamiliar with common platforms. Some youth may prefer virtual spaces and might be more familiar with them than adults. Nevertheless, we should be careful to neither underestimate nor overestimate youth abilities to navigate and use technology. Just as for adults, virtual meetings and related software provide an essential opportunity. For example, virtual meetings may provide the benefits of breadth of interests, such as sharing meaningful belongings, and depth of conversation, such as sharing home lives. Many leaders are sustaining programs virtually and how they choose to proceed will matter for maintaining youth-adult relationships. Synchronous, real-time meetings-rather than only sending youth activities to complete on their own-are important for youth to maintain social connections with their leaders and peers. Practitioners (and many researchers) are already devoting time to professional development to learn to use and maximize virtual meeting platforms (e.g., Zoom hosts free and interactive live training webinars). Some may also consider devoting professional development time to strengthening staff understanding of the importance of relationships and building relational capacities in other ways (e.g., The Aspen Institute's National Commission on Social, Emotional, and Academic Development provides a variety of online resources). The key is to focus on developing and/or sustaining meaningful relationships and the capacities needed for them.

Virtual meetings can also be used in more innovative ways, such as parallel play, where the adult and youth engage in similar activities in different places (e.g., baking or making art together). Some people are also finding creative ways to meet while social distancing. For example, a schoolteacher in South Dakota became an internet sensation because he went to his student's house to give her math lessons on her front porch and through the protection of a glass door (Lee, 2020). Table 1 provides additional examples of innovative ways in which youth and families are sustaining, adapting, or creating opportunities for adult-youth relationships during the pandemic. 
Journal of Youth Development | http://jyd.pitt.edu/ | Vol. 15 Issue 2 DOI 10.5195/jyd.2020.962

Youth Leisure During a Pandemic

Table 1. Supporting Youth-Adult Relationships During the COVID-19 Pandemic

\begin{tabular}{|c|c|c|}
\hline Organization & Description & Website \\
\hline $\begin{array}{l}\text { The Aspen Institute's } \\
\text { Project Play }\end{array}$ & $\begin{array}{l}\text { Ideas for parents and coaches to } \\
\text { keep kids active and keep athletic } \\
\text { teams engaged, such as having the } \\
\text { team watch a sports movie and then } \\
\text { come together virtually to discuss } \\
\text { the lessons learned. }\end{array}$ & $\begin{array}{l}\text { https://www.aspenprojectplay.org/cor } \\
\text { onavirus-and-youth-sports/\#how-do- } \\
\text { you-keep-kids-physically-active-if- } \\
\text { schools-and-sports-are-closed }\end{array}$ \\
\hline Search Institute & $\begin{array}{l}\text { Tip sheet to help adults nurture PYD } \\
\text { among the youth in their lives. }\end{array}$ & $\begin{array}{l}\text { https://www.search-institute.org/wp- } \\
\text { content/uploads/2020/03/SI- } \\
\text { coronavirus-tipsheet.pdf }\end{array}$ \\
\hline $\begin{array}{l}\text { MENTOR (The } \\
\text { National Mentoring } \\
\text { Partnership) }\end{array}$ & $\begin{array}{l}\text { E-mentoring platform, and resources } \\
\text { for mentors engaging virtually with } \\
\text { youth. }\end{array}$ & $\begin{array}{l}\text { https://www.mentoring.org/coronavir } \\
\underline{\text { us-resources/ }}\end{array}$ \\
\hline $\begin{array}{l}\text { Many local } \\
\text { organizations (e.g., } \\
\text { Living Classrooms in } \\
\text { Baltimore and Seven } \\
\text { Tepees Youth } \\
\text { Program in San } \\
\text { Francisco, Crittenton } \\
\text { Services of Greater } \\
\text { Washington) }\end{array}$ & $\begin{array}{l}\text { Staff at many organizations serving } \\
\text { under-resourced youth are calling or } \\
\text { texting students and their families to } \\
\text { check in, or connecting with youth } \\
\text { through social media. }\end{array}$ & $\begin{array}{l}\text { https://livingclassrooms.org/important } \\
\text {-safety-updates-living-classrooms- } \\
\text { global-pandemic/ } \\
\text { https://www.seventepees.org/ } \\
\text { https://hechingerreport.org/helping- } \\
\text { kids-who-are-feeling-isolated-and- } \\
\text { anxious-after-schools-shut-down/ }\end{array}$ \\
\hline Fuller Youth Institute & $\begin{array}{l}\text { Guidance for youth ministry during } \\
\text { the pandemic, including creating } \\
\text { spaces for youth to pray for the } \\
\text { world and those most impacted. }\end{array}$ & $\begin{array}{l}\text { https://fulleryouthinstitute.org/blog/d } \\
\text { oing-youth-ministry-during-a- } \\
\text { pandemic }\end{array}$ \\
\hline $\begin{array}{l}\text { The Collaborative for } \\
\text { Academic, Social, and } \\
\text { Emotional Learning } \\
\text { (CASEL) }\end{array}$ & $\begin{array}{l}\text { Resources for parents and educators } \\
\text { to help support youth and } \\
\text { strengthen relationships. }\end{array}$ & https://casel.org/covid-resources/ \\
\hline
\end{tabular}




\section{Skill-Building Activities}

The second of the Big Three features is youth engagement in skill-building activities. There may be a tendency during the pandemic to relax rules and allow youth infinite unstructured free time. Youth are, of course, going through a crisis and experiencing incredible change with little notice. However, even a small "dose" (e.g., several weeks) of unstructured leisure can negatively affect youth developmental pathways. For example, youth who lack structured leisure opportunities in the summer lag behind their peers academically at the beginning and across the next school year, a phenomenon referred to as "summer loss" (Cooper et al., 2000). To offset these declines, it will be important to identify skill-building activities that can be modified based on individual situations and that meaningfully engage youth during the pandemic (focusing on youth experience of the activity, rather than just the outcome of it). These activities may be the same ones as those which occur in their youth programs, although the form of engagement may differ, or youth may be inspired to engage in new activities.

There are many challenges to adapting program activities to be online. Many activities, such as sports, are not easily adapted to virtual meetings. Moreover, many youth lack materials, space, or equipment at home to engage in these types of activities. Another challenge may be that skill-building activities often require assistance or scaffolding from adults who may not be physically present to guide learning. Youth who do not have an adult available to help (e.g., youth whose parents are working from home or are essential workers) or whose parents are under extreme stress (e.g., youth whose parents are coping with job loss or financial strain) may find it challenging to seek out skill-building opportunities during the pandemic. When parents are available, there may be a learning curve for them to be able to support youth (e.g., many parents are relearning early school subjects to help youth with school lessons;

Edwardson, 2020). A primary challenge may be determining what youth or families need during the pandemic, yet this also presents an opportunity. One way to address youth and family needs through skill-building activities is to engage youth in research and evaluation, such as needs-based assessments. Needs-based assessments are useful to determine and address needs of youth served by the program, can be done online and with minimal resources, and will help sustain programs through and after the pandemic (e.g., Jones, \& Perkins, 2003). The challenge is to find innovative ways to engage youth in whatever ways make sense for their pandemic situation and to make such adaptations for each individual youth in the program.

The pandemic may also present new opportunities for skill-building activities. As families are restricted to their homes, they may find opportunities for family activities that were not 
previously available. Cooking has become a popular pastime for many homebound adults during the pandemic, which could present an opportunity to teach youth cooking or other related life skills. For example, a bakery on the brink of closure due to the pandemic began selling at-home pizza-making kits to encourage families to make dinner together (Barnett, 2020). Games can also be skill-building activities and can be solitary or social. Games of strategy (e.g., board games), chance (e.g., card games), cooperation (e.g., team-based games) or creativity (e.g., charades) can help youth build strategic thinking, interpersonal skills, and social-emotional capacities. There is also an abundance of media-based games that are skill-building and that can be played virtually with friends (note that it will be important to monitor youth internet use to avoid predators). There are also many authors and artists livestreaming their work and producing activities for youth, which could be skill-building if youth are learning to follow complex storylines, or producing or learning about art. Innovative examples of skill-building activities to engage youth during the pandemic are provided in Table 2.

\section{Table 2. Supporting Youth Skill-Building During the COVID-19 Pandemic}

\begin{tabular}{|l|l|l|}
\hline Organization & Description & Website \\
\hline $\begin{array}{l}\text { Living Classrooms in } \\
\text { Baltimore }\end{array}$ & $\begin{array}{l}\text { Staff are engaging youth in a variety } \\
\text { of activities, by providing STEAM } \\
\text { activity boxes for families to pick up } \\
\text { at food distribution sites and holding } \\
\text { virtual music classes. }\end{array}$ & $\begin{array}{l}\text { https://livingclassrooms.org/important } \\
\text {-safety-updates-living-classrooms- } \\
\text { global-pandemic/ }\end{array}$ \\
\hline $\begin{array}{l}\text { Northern Stage } \\
\text { theater company in } \\
\text { VT }\end{array}$ & $\begin{array}{l}\text { Hosting a virtual youth program } \\
\text { involving journaling and the group } \\
\text { creation of a documentary play. }\end{array}$ & $\begin{array}{l}\text { https://northernstage.org/youth- } \\
\text { training/portraits-of-the-pandemic/ }\end{array}$ \\
\hline The Center for Native & $\begin{array}{l}\text { Recommending young people use } \\
\text { this time to connect with their } \\
\text { American Youth at } \\
\text { the Aspen Institute }\end{array}$ & $\begin{array}{l}\text { https://www.cnay.org/using-art- } \\
\text { cultural heritage. }\end{array}$ \\
\hline 4-H & $\begin{array}{l}\text { language-and-traditional-foods-as-a- } \\
\text { youth in 4-H programs to continue } \\
\text { way-of-healing/ }\end{array}$ \\
\hline $\begin{array}{l}\text { learning and building new skills while } \\
\text { social distancing. }\end{array}$ & https://4-h.org/about/4-h-at-home/ \\
\hline
\end{tabular}


Table 2. (continued)

\begin{tabular}{|c|c|c|}
\hline Organization & Description & Website \\
\hline $\begin{array}{l}\text { Active Healthy Kids } \\
\text { global alliance }\end{array}$ & $\begin{array}{l}\text { Encouraging families to help youth } \\
\text { stay physically active during the } \\
\text { pandemic. }\end{array}$ & $\begin{array}{l}\text { https://www.activehealthykids.org/20 } \\
\text { 20/04/06/quidance-on-healthy- } \\
\text { movement-behaviours-for-kids- } \\
\text { during-the-covid-19-pandemic/ }\end{array}$ \\
\hline $\begin{array}{l}\text { Public Broadcasting } \\
\text { Service (PBS) }\end{array}$ & $\begin{array}{l}\text { Providing educational games and } \\
\text { skill-building activities for children } \\
\text { and families. }\end{array}$ & $\begin{array}{l}\text { https://www.pbs.org/about/blogs/ne } \\
\text { ws/pbs-responds-to-coronavirus- } \\
\text { pandemic-with-programming-and- } \\
\text { online-content-to-keep-americans- } \\
\text { informed-and-support-families-and- } \\
\text { educators/ }\end{array}$ \\
\hline LiveScience & $\begin{array}{l}\text { Updating their website with } \\
\text { educational activities and online } \\
\text { resources for kids. }\end{array}$ & $\begin{array}{l}\text { https://www.livescience.com/coronavi } \\
\underline{\text { rus-kids-activities.html }}\end{array}$ \\
\hline
\end{tabular}

\section{Leadership Opportunities}

The third of the Big Three features is opportunities to lead and enact skills in valued family, community, or school settings. Many youth who were leading initiatives through OST programs may have experienced an abrupt halt to their important work. For example, the pandemic forced one youth-serving organization, Boys \& Girls Club of Dane County, Wisconsin, to cancel their annual Shamrock Shuffle race, a fundraising event that raises over $\$ 100,000$ for local youth (Almenara, 2020). Instead of waiting until after the pandemic to resume these programs and events, youth, such as those involved in the Boys \& Girls Club, can rethink their fundraising strategies and be creative with online donation platforms (Waldon, 2020). Youth can also shift their focus to new leadership initiatives within their programs. For example, as described earlier, youth can learn to design and implement needs-based assessments during the pandemic and can take a more meaningful leadership approach by utilizing youth-led participatory action research ([YPAR]; e.g., Ozer, 2016). YPAR is used to address youth and community needs, but is based in social justice principles that redefine expertise and power as shared between youth and adults. Youth who cannot continue their leadership initiatives within their programs might shift their focus to new initiatives, such as YPAR, which can be accessed through a variety of online resources, such as the YPAR Hub at the University of California, Berkeley. 


\section{Youth Leisure During a Pandemic}

Importantly, youth do not need to be affiliated with a program to make a difference during the pandemic. The pandemic presents abundant opportunities to make a difference in local and global ways. The challenge may be that it is hard to know what actions to take, what initiatives to launch, or to which campaigns to contribute. There is often misinformation or little helpful information made available to the public about catastrophic events; this inhibits youth abilities to know how to make an impact or to understand who is in need. Moreover, it is difficult to make a difference in the community when people are restricted from physically being in the community. Youth may be particularly challenged to find leadership opportunities if they have few material and financial resources or limited social networks to engage for information or support. Another resource often touted as inhibiting youth or family engagement in social initiatives is time. During the pandemic, however, time is plentiful for some and may be applied through leadership initiatives that help affected communities. Of course, we acknowledge that time is not a resource that all youth and families are experiencing during the pandemic. Many families, such as intergenerational families, large families, families with young or many children, families with parents who are simultaneously working from home and homeschooling their children, or families trying to keep struggling businesses afloat, may have limited time. Moreover, youth may have shifting responsibilities that prohibit their engagement in community-level, leisure-time leadership roles; these youth might turn inward for new leadership opportunities within the family (e.g., caring for siblings or preparing family meals).

For youth who are able to engage in leadership opportunities, serving affected communities is a relevant and meaningful way to apply and develop skills. Youth can launch their own initiatives or contribute to local or global initiatives. For example, two teenagers in Maryland caught the attention of CNN for organizing and leading an initiative to deliver food to the elders in their community (Dawson, 2020). Youth can become involved in local or global initiatives by soliciting donations, organizing deliveries, identifying those in need, or raising money through virtual platforms, such as GoFundMe. Importantly, youth do not need to focus their attention outwardly on their communities to make a difference. Youth can make an impact at home by organizing family time, presenting ideas for family activities, and, if needed, by helping their families find donated supplies through community websites, such as Facebook or Nextdoor. Additional ideas for involving youth in leadership opportunities during the pandemic are presented in Table 3. 
Journal of Youth Development | http://jyd.pitt.edu/ | Vol. 15 Issue 2 DOI 10.5195/jyd.2020.962

Youth Leisure During a Pandemic

Table 3. Supporting Youth Leadership During the COVID-19 Pandemic

\begin{tabular}{|c|c|c|}
\hline Organization & Description & Website \\
\hline $\begin{array}{l}\text { Youth } \\
\text { everywhere }\end{array}$ & $\begin{array}{l}\text { Youth all over the country are } \\
\text { sewing masks to help keep } \\
\text { people safe in their communities. }\end{array}$ & $\begin{array}{l}\text { https://www.pressconnects.com/story/news/loc } \\
\text { al/2020/04/13/coronavirus-all-saints-fifth- } \\
\text { grader-sews-masks-health-care-workers- } \\
\text { binghamton/2953342001/ } \\
\text { https://www.khou.com/article/news/health/coro } \\
\underline{\text { navirus/league-city-siblings-combine-special- }} \\
\underline{\text { talents-to-make-mask-for-frontline- }} \\
\underline{\text { workers/285-80ae9ee5-e61d-4abf-a41c- }} \\
\underline{\text { 16d1a189d66c }} \\
\underline{\text { https://www.onfocus.news/local-4-h-kids-sew- }} \\
\underline{\text { 120-masks-for-local-medical-professionals/ }}\end{array}$ \\
\hline $\begin{array}{l}\text { Youth } \\
\text { everywhere }\end{array}$ & $\begin{array}{l}\text { Youth climate activists are } \\
\text { conducting online strikes. }\end{array}$ & $\begin{array}{l}\text { https://www.commondreams.org/news/2020/03 } \\
\text { L13/coronavirus-isnt-stopping-us-youth- } \\
\text { activists-adapt-global-pandemic-digital }\end{array}$ \\
\hline $\begin{array}{l}\text { The Wilder } \\
\text { Foundation } \\
\text { Youth } \\
\text { Leadership } \\
\text { Initiative in } \\
\text { Minnesota }\end{array}$ & $\begin{array}{l}\text { Moved programming online so } \\
\text { youth can continue to work on } \\
\text { their service projects. }\end{array}$ & $\begin{array}{l}\text { https://www.wilder.org/articles/youth- } \\
\text { leadership-initiative-continues-building- } \\
\text { community-and-leadership-online-during }\end{array}$ \\
\hline $\begin{array}{l}\text { Psychology } \\
\text { Today }\end{array}$ & $\begin{array}{l}\text { Advising parents to use family } \\
\text { meetings as a vehicle for youth } \\
\text { leadership development. }\end{array}$ & $\begin{array}{l}\text { https://www.psychologytoday.com/us/blog/the- } \\
\text { moment-youth/201902/nurturing-youth- } \\
\text { leadership-skills-home }\end{array}$ \\
\hline $\begin{array}{l}\text { The } \\
\text { International } \\
\text { Youth } \\
\text { Foundation }\end{array}$ & $\begin{array}{l}\text { Highlighting the efforts of youth } \\
\text { leaders around the world on } \\
\text { their social media. }\end{array}$ & $\begin{array}{l}\text { https://www.facebook.com/iyfnet/photos/a.101 } \\
\text { 50604187931467/10156569263626467/?type=3 } \\
\text { \&theater }\end{array}$ \\
\hline $\begin{array}{l}\text { Colorado Crisis } \\
\text { Services }\end{array}$ & $\begin{array}{l}\text { Youth leaders are developing a } \\
\text { campaign to raise awareness of } \\
\text { mental health during the } \\
\text { pandemic. }\end{array}$ & $\begin{array}{l}\text { https://kdvr.com/news/teens-working-on-new- } \\
\text { anxiety-depression-campaign-for-those- } \\
\text { affected-by-covid-19/ }\end{array}$ \\
\hline
\end{tabular}


Table 3. (continued)

\begin{tabular}{|l|l|l|}
\hline Organization & Description & Website \\
\hline YouthLead & $\begin{array}{l}\text { Highlighting the efforts of youth } \\
\text { leaders around the world, and } \\
\text { empowering young people to } \\
\text { take a stand against COVID-19. }\end{array}$ & $\begin{array}{l}\text { https://www.youthlead.org/innovations/youthle } \\
\text { ad-response-global-covid-19-pandemic }\end{array}$ \\
\hline The Root & $\begin{array}{l}\text { Identified 25 youth leaders for } \\
\text { their Young Futurists 2020 } \\
\text { award, remembering that } \\
\text { leadership is important in all } \\
\text { areas, not just pandemic } \\
\text { response. }\end{array}$ & $\underline{\underline{\text { https://www.theroot.com/young-futurists-2020- }}}$ \\
\hline
\end{tabular}

\section{Uniting to Engage and Serve Youth: A Call to Action}

We know from ecological systems theory (Bronfenbrenner \& Morris, 2006) and life course research (e.g., Elder, 2018) that youth lives are embedded in and shaped by historical events, such as the COVID-19 pandemic. Indeed, the pandemic will leave its mark on youth and their families immediately and for many years and generations to follow. The developmental impact of the pandemic will likely vary depending on youth positions in the life course (Elder, 2018). For example, younger youth will not yet have developed the social and emotional capacities (e.g., emotion regulation, empathy) to fully manage a major crisis and older youth participating in the labor force may face additional challenges of unemployment or the need to continue working in "essential" positions (e.g., grocery store workers). The impact on youth will also vary based on when the pandemic occurs relative to other major life events (Elder, 2018). For example, some youth may be experiencing their first-ever public crisis, whereas other youth may have experience weathering natural disasters or other large-scale crises. Some youth may also be experiencing a compounding of major life events (e.g., parental divorces, loss of proms and graduation ceremonies, changing family structures, grieving recent losses) and crises in multiple areas within their ecological systems (e.g., parental or personal unemployment, school closures, loss of recreational activities). In short, each youth will experience the pandemic differently and the pandemic will impact each of their lives differently. We therefore end with a call to researchers and practitioners to unite efforts, using scholarly knowledge from youth development research and practical wisdom from youth development programs, to support youth while taking into account their complex and unique experiences. 


\section{Adapt to Shifting Needs}

In navigating these difficult times, we recommend that youth programs adapt what they do to promote PYD while remaining focused on their theory of change; the roadmap for why and how the program operates. The pandemic has current and potentially long-term impacts on many youth programs, especially smaller programs and nonprofits that lack the resources to cover expenses while their programming is interrupted. Just as many people are losing their lives to COVID-19, many businesses and organizations are also closing or fighting to survive. Maintaining the focus on how and why they do what they do, whether a program is based on the Big Three (as modeled here) or another youth development model, will help keep the program itself on course even as program delivery and content adapt to the changing world around us. Every organization will have to find their own way to navigate the new normal, based on local context and the specific needs of youth, but grounding these adaptations in the program's theory of change will ensure that this work continues to best serve the organization's mission and youth.

\section{Re-Focus on Practitioner Support}

In turn, we recommend that researchers be intentional about discovering the needs, challenges, and opportunities that arise during the pandemic for youth and the practitioners who serve them. Researchers should continue to do what they do best - research - however, research is a long-term investment that often has a delayed impact. Moreover, taking care not to exploit vulnerable populations through the research process will be of utmost importance. For immediate impact, research can be applied to support youth development practice. Practitioners have a wealth of information about the experiences of local communities and how to make an impact. Researchers can identify research- and evidence-based tools that might be useful for practitioners (e.g., tools that address factors like resilience, coping, relationships, policy, and discrimination are great starting points). However, to be effective in supporting youth, research-practice integration must be a two-way street, involving genuine partnerships between researchers and practitioners (Agans et al., 2020; Ettekal et al., 2017). In these challenging times, we suggest that those with more resources, such as researchers who have the privilege of being employed through the pandemic, turn to help their colleagues in need. Researchers can support struggling youth programs by helping to write grants, donating to youth-serving non-profits, and reaching out to practitioner colleagues and youth to find out what assistance they most need in this time. 


\section{Recognize and Invent Future Possibilities}

Ultimately, we recommend that researchers and practitioners with secure positions and the opportunity to reflect should partner together to help shape the future of OST and PYD. While many are caught up in the immediacy of the crisis, thinking about the possibilities presented as we all begin to define a new normal is essential to move forward. While considering the new normal, there should be recognition that practitioners are more likely to be on the front lines of the pandemic's economic impact while researchers are often more protected. Researchers and practitioners will need to think carefully and practically about how youth and families can be supported through the summer, as policies begin to change with regard to opening businesses and recreational facilities. As we move into fall, what could and should OST and use of leisure time look like for youth as schools move to early starts, alternate days, or year-round schooling?

Predicting the future is difficult even under normal circumstances. Now that the future is even more unpredictable, research and theories of change can be the lighthouses in the storm. Our field has an abundance of theoretical models to support youth development and, as illustrated in this commentary, these theories can be used to guide the adaptation of programming as leisure time, school, and family contexts become more closely intertwined during the pandemic. These adaptations will need to be flexible to account for the unique constellations of challenges each family faces, and to work within the constraints faced by each youth-serving organization.

\section{Invest in Practitioner Professional Development}

As the youth sector navigates a new normal, we recommend searching for and investing in the professional development and training of the adults who most influence young people's learning and development. Despite immediate challenges, the disruption in service delivery and the related potential freeing up of time (and unfortunate loss of jobs) may make professional development viable during the pandemic. We noted above the importance of youth-adult relationships. The pandemic has given too many professionals in the youth development field more free time, however unfortunate, and these professionals have not stopped caring and worrying about their youth. The youth development sector should pursue innovative ways to invest in the workforce, pay for professional development where possible, and create spaces and resources for staff to invest in their own professional growth. Programs should explore how they can strengthen their workforce as well as support them during these times or risk them 
leaving their programs or the youth development field altogether. To support these efforts, many intermediaries (e.g., the members of Every Hour Counts), as well as statewide afterschool networks and associations (e.g., the National Afterschool Association), are increasing access to virtual professional development opportunities.

In conclusion, we will also need to be supportive of each other, both professionally and in recognition that many of us are facing this pandemic both as researchers or practitioners AND as parents or caregivers. Nevertheless, even as the pandemic creates new challenges and exacerbates existing disparities, opportunities to foster positive youth development persist as does our capacity to promote that development through our intentional actions. It will be up to us to sustain, adapt, and create the elements that we know work to support youth development during the pandemic.

\section{Acknowledgements}

We thank Dale Blyth for his excellent feedback and recommendations to improve this commentary.

\section{References}

Agans, J. P., Burrow, A. L., Kim, E. S., Garbo, C., Schroeder, M., Graf, S., \& Davis, T. (2020). "You're going to burn some bridges if you come at it the wrong way": Reflecting on the realities of research-practice partnerships. Community Development, online first, 1-17. https://doi.org/10.1080/15575330.2020.1714686

Almenara, F. (2020, March 12). Madison Shamrock Shuffle canceled, big loss for Boys and Girls Club. WKOW. https://wkow.com/2020/03/12/madison-shamrock-shuffle-canceled-big-loss-for-boysand-girls-club/

Arnold, M. E. (2018). From context to outcomes: A thriving model for 4-H youth development programs. Journal of Human Sciences and Extension, 6(1), 141-160.

https://www.jhseonline.com/article/view/653

Barnett, H. (2020, April 9). Blue Baker approaches COVID-19 situation with adjustments, comic relief. KBTX-TV. https://www.kbtx.com/content/news/Blue-Baker-making-the-most-out-of-their-COVID19-situation-569518421.html

Benson, P. L., Scales, P. C., \& Syvertsen, A. K. (2011). The contribution of the developmental assets framework to positive youth development theory and practice. In R. M. Lerner, J. V. Lerner, \& J. 
Journal of Youth Development | http://jyd.pitt.edu/ | Vol. 15 Issue 2 DOI 10.5195/jyd.2020.962

Youth Leisure During a Pandemic

B. Benson (Eds.), Positive youth development. Advances in child development and behavior (Vol. 41, pp. 195 - 228). Elsevier.

Bouffard, S. M., Wimer, C., Caronongan, P., Little, P., Dearing, E., \& Simpkins, S. D. (2006). Demographic differences in patterns of youth out-of-school time activity participation. Journal of Youth Development, 1(1), 24-40. https://doi.org/10.5195/jyd.2006.396

Bowers, E. P., Geldhof, G. J., Schmid, K. L., Napolitano, C. M., Minor, K., \& Lerner, J. V. (2012). Relationships with important nonparental adults and positive youth development: An examination of youth self-regulatory strengths as mediators. Research in Human Development, 9(4), 298316. https://doi.org/10.1080/15427609.2012.729911

Bronfenbrenner, U., \& Morris, P. A. (2006). The bioecological model of human development. In W. Damon \& R. M. Lerner (Eds.), Handbook of child psychology: Vol. I. Theoretical models of human development (6 $6^{\text {th }}$ ed., pp. 793-828). John Wiley \& Sons.

Cantor, P., Osher, D., Berg, J., Steyer, L., \& Rose, T. (2019). Malleability, plasticity, and individuality: How children learn and develop in context. Applied Developmental Science, 23(4), 307-337. https://doi.org/10.1080/10888691.2017.1398649

Cooper, B., Charlton, K., Valentine, J. C., \& Muhlenbruck, L. (2000). Making the most of summer school: A meta-analytic and narrative review. Monograph Series for the Society for Research in Child Development, 65(1), 1-118.

Dawson, C. (2020, April 15). Teens start free no-contact delivery service for the elderly during the pandemic. CNN. https://www.cnn.com/2020/04/15/us/iyw-teens-delivery-service-for-the-elderlytrnd/index.html

Edwardson, L. (2020, 22 April). Calgary parents struggle to homeschool during COVID-19 pandemic. CBC. https://www.cbc.ca/news/canada/calgary/calgary-parents-homeschool-pandemic-1.5535203

Elder, G. H. (2018). Children of the Great Depression: Social change in life experience (25 ${ }^{\text {th }}$ anniversary ed.). Routledge.

Ettekal, A. V., Konowitz, L. S., Agans, J. P., Syer, T., \& Lerner, R. M. (2017). Researcher-practitioner collaborations: Applying developmental science to understand sport participation and positive youth development. Journal of Community Engagement \& Higher Education, 9(1), 29-45.

Ettekal, A. V., \& Mahoney, J. L. (2017). Ecological systems theory. In K. Peppler (Ed.), The Sage encyclopedia of out-of-school learning (pp. 239 - 241). SAGE Publishing.

Ettekal, A. V., Simpkins, S. D., Menjivar, C., \& Delgado, M. Y. (2020). The complexities of culturally responsive organized activities: Latino parents' and adolescents' perspectives. Journal of Adolescent Research, 35, 395-426. https://doi.org/10.1177/0743558419864022

Grossman, J. B., \& Rhodes, J. E. (2002). The test of time: Predictors and effects of duration in youth mentoring relationships. American Journal of Community Psychology, 30(2), 199-219. https://doi.org/10.1023/A:1014680827552 
Journal of Youth Development | http://jyd.pitt.edu/ | Vol. 15 Issue 2 DOI 10.5195/jyd.2020.962

Youth Leisure During a Pandemic

Jones, K. R., \& Perkins, D. F. (2003). CAYDO: Connecting the gaps of community youth assessments. Journal of Extension, 41(6). https://www.joe.org/joe/2003december/a2.php

Larson, R. W. (2000). Toward a psychology of positive youth development. American Psychologist, 55(1), 170-183. https://doi.org/10.1037/0003-066X.55.1.170

Larson, R. W., Eccles, J., \& Gootman, J. A. (2004). Features of positive developmental settings. Prevention Researcher, 11(2), 8-13.

Lee, A. (2020, March 31). Math teacher shows up at student's front porch to give her a one-on-one lesson while social distancing. CNN. https://www.cnn.com/2020/03/31/us/coronavirus-mathlesson-teacher-trnd/index.html

Lerner, R. M., Lerner, J. V., \& Benson, J. B. (2011). Positive youth development: Research and applications for promoting thriving in adolescence. In Advances in child development and behavior (Vol. 41, pp. 1-17). https://doi.org/10.1016/B978-0-12-386492-5.00001-4

Lerner, R. M., Lerner, J. V., Lewin-Bizan, S., Bowers, E. P., Boyd, M. J., Mueller, M. K., Schmid, K. L., \& Napolitano, C. M. (2011). Positive youth development: Processes, programs, and problematics. Journal of Youth Development, 6(3), 38-62. https://doi.org/10.5195/jyd.2011.174

Mahoney, J. L., Vandell, D. L., Simpkins, S., \& Zarrett, N. (2009). Adolescent out-of-school activities. In R. M. Lerner and L. Steinberg (Eds.), Handbook of Adolescent Psychology: Vol. 2: Contextual Influences on Adolescent Development ( $3^{\text {rd }}$ ed., pp. 228-269). John Wiley \& Sons. https://doi.org/10.1002/9780470479193.adlpsy002008

Nagaoka J., Farrington, C.A., Ehrlich, S.B., \& Heath, R.D. (2015) Foundations for young adult success: $A$ developmental framework. Concept paper for research and practice. The University of Chicago Consortium on Chicago School Research.

https://consortium.uchicago.edu/sites/default/files/201810/Foundations\%20for\%20Young\%20Adult-Jun2015-Consortium.pdf

Osher, D., Cantor, P., Berg, J., Steyer, L. \& Rose, T. (2020). Drivers of human development: How relationships and context shape learning and development. Applied Developmental Science, 24(1), 3-36. https://doi.org/10.1080/10888691.2017.1398650

Ozer, E. J. (2016). Youth-led participatory action research: Developmental and equity perspectives. In Advances in child development and behavior (Vol. 50, pp. 189-207). https://doi.org/10.1016/bs.acdb.2015.11.006

Pittman, K. (2020, March 30). What happens when out-of-school time is all the time? The Forum for Youth Investment. https://forumfyi.org/blog/what-happens-when-out-of-school-time-is-all-thetime/

Roth, J. L., \& Brooks-Gunn, J. (2003). What exactly is a youth development program? Answers from research and practice. Applied Developmental Science, 7(2), 94-111. https://doi.org/10.1207/S1532480XADS0702 6 
Journal of Youth Development | http://jyd.pitt.edu/ | Vol. 15 Issue 2 DOI 10.5195/jyd.2020.962

Youth Leisure During a Pandemic

Simpkins, S., Ripke, M., Huston, A., \& Eccles, J. (2005). Predicting participation and outcomes in out-ofschool activities: Similarities and differences across social ecologies. New Directions for Youth Development, 105, 51-69, 10. https://doi.org/10.1002/yd.107

U.S. Department of Labor. American Time Use Survey; 2018. https://www.bls.gov/tus/

Waldon, T. (2020, March 13). Fundraising events are cancelled. Giving is decreasing. What Now? Give. https://givewp.com/fundraising-events-are-cancelled-giving-is-decreasing-what-now/

Walker, G. J., Kleiber, D. A., \& Mannell, R. C. (2019). A Social Psychology of Leisure (3 ${ }^{\text {rd }}$ ed). SagamoreVenture Publishing. 